\title{
Toimijuuden vahvistumisen edellytykset kuntouttavassa työtoiminnassa
}

Päivi Mäntyneva

\section{TIIVISTELMÄ}

Artikkelissa kysytään, miten osallistujien toimijuus voi vahvistua kuntouttavassa työtoiminnassa. Metodologisena lähtökohtana on institutionaalinen etnografia. Etnografinen tutkimusaineisto koostuu etnografisista haastatteluista ja osallistuvaan havainnointiin pohjautuvista kenttäpäiväkirja-aineistoista. Haastatteluaineisto analysoitiin sisällönanalyysillä. Analysoinnin kehyksenä sovellettiin toimijuuden modaliteettiteoriaa. Tutkimuksen tulokset havainnollistavat yhteiskunnan integraatiotehtävän ja emansipaation jännitteistä suhdetta. Tutkimustulokset lisäävät ymmärrystä siitä, miten motivaatio ja sitoutuminen, tarve kuntoutukselliselle toiminnalle ja myönteiset lähitulevaisuuden horisontit vahvistavat toimijuutta. Kuntouttavan työtoiminnan emansipatoriset elementit jäävät kuitenkin niukoiksi. Tämä johtuu kaventuneista tulevaisuuden näköaloista, ajallisesti rajallisesta jaksosta kuntouttavassa työtoiminnassa sekä toiminnan mahdollistamista vähäisistä myönteisistä siirtymistä.

Avainsanat: toimijuus, voimaantuminen, valtaantuminen, kuntouttava työtoiminta, institutionaalinen etnografia 


\section{ABSTRACT \\ PREREQUISITES FOR STRENGTHENING THE HUMAN AGENCY IN REHABILITATIVE WORK ACTIVITIES}

- In this research article, it's asked, how human agency of the participants can be strengthened in rehabilitative work activities. The methodological starting point is institutional ethnography. Ethnographical research material consists thematic interviews and field diaries based on participatory observation. The research material was analysed by content analysis. The modality theory of the human agency was applied as a framework for the analysis. Research results demonstrates, the tension between social integration and emancipation. Research findings deepens understanding, how empowerment relates to the motivation, commitment, the need for rehabilitative activities and expected future horizonts. However, the emancipatory elements of rehabilitative work activities remain scarce. This is due to participants' narrowed expectations of the future, limited time-period in rehabilitative work activities and lack of positive transitions offered by welfare service system.

Key words: human agency, empowerment, rehabilitative work activities, institutional ethnography

\section{Johdanto}

$\mathrm{K}$ eväällä 2018 julkaistiin Hallituksen asettaman yhteiskunnallista eriarvoisuutta käsitelleen Juho Saaren johtaman työryhmän loppuraportti. Sen keskeinen viesti on, että yhteiskunnallinen eriarvoisuus aiheutuu enemmän myönteisten siirtymien epätasaisesta jakautumisesta ja hyväosaisuuden yleistymisestä kuin laaja-alaisesta huono-osaisuuden kasautumisesta (Eriarvoisuutta käsittelevän työryhmän loppuraportti 2018). Myönteisillä siirtymillä tarkoitetaan palvelujärjestelmässä esimerkiksi erilaisia sosiaali- ja työvoimapoliittisia siirtymiä ja toimijuuden suunnan muutoksia, joiden myötä osallistujien kokema hyvä elämä lisääntyy. Ne ovat monenlaisia ihmisten sosiaalista osallisuutta ja toimintakykyä vahvistavia tai niitä ylläpitäviä intentioita, jotka tukevat ihmisten pyrkimyksiä autonomiseen ja luovaan toimijuuteen (Hiilamo \& Saari 2010, 14-15). Myönteiset siirtymät voivat olla lisäksi merkityksen muutoksia ihmisten elämänkentässä.

Pitkään työttömänä olleet eivät ole hyötyneet väestön enemmistön tapaan yleisestä hyvinvoinnin lisääntymisestä. Vaikka työttömyys on ti- 
lastollisesti vähentynyt Suomessa, ei vaikeasti työllistyvien tilanne ole kohentunut merkittävästi ja mahdollisuudet myönteisiin siirtymiin ovat loitontuneet. Tutkijat puhuvat jo pitkään työttömänä olleiden kohdalla kroonisesta työttömyydestä (Aho \& Mäkiaho 2016). Arkipäivisin tuhannet ihmiset lähtevät kuntouttavaan työtoimintaan. Vuonna 2016 osallistujia oli lähes 42000 (Virtanen 2017). Poliittisessa keskustelussa ja tutkimuksissa kuntouttava työtoiminta on määrittynyt niin sosiaaliseksi työllistämiseksi, välityömarkkinoiksi, työelämäosallisuuden tyyssijaksi kuin sosiaalisen vahvistamisen areenaksi (Välimaa, Ylipaavalniemi, Pikkusaari \& Hassinen 2012; Filatov 2013; Sosiaalihuollon työelämäosallisuutta tukevan... 2014). Näiden määrittelyjen kautta työtoiminnan kentät tulevat osaksi aikakauden omaa eetosta (esim. Rajavaara 2007). Ne ovat siten sosiaalisia käytäntöjä, jotka syntyvät, vakiinnuttavat toimintansa, uusiutuvat ja uudistuvat (Shove, Pantzar \& Watson 2012).

Kuntouttavan työtoiminnan päämääränä on ollut tukea osallistujien elämänhallintaa sekä edistää työelämävalmiuksia. Työllisyyden edistämisessä kuntouttava työtoiminta ei kuitenkaan ole osoittautunut merkitykselliseksi. Monissa tutkimuksissa on tunnistettu monenlaisia työtoiminnan hyvinvointivaikutuksia, vaikka tutkimustulokset ovat olleet osin ristiriitaisia (Karjalainen \& Karjalainen 2010; Kotiranta 2008; Luhtasela 2009; Mäntyneva \& Hiilamo 2018; Mäntyneva \& Isola 2019; Sandelin 2014; Tammelin 2010).

Tässä artikkelissa kysyn, miten toimijuus voi vahvistua kuntouttavassa työtoiminnassa. Pohdin myös sitä, millaisia reunaehtoja toimijuuden vahvistumiseen liittyy. Avaan seuraavassa luvussa teoreettisia ja empiirisiä näköaloja toimijuuteen. Lähestyn artikkelissa toimijuutta dynaamisena prosessina ja relationaalisena suhteena yksilön, yhteisöjen ja yhteiskunnan välillä. Tutkimuksen toteutusluvussa kuvaan artikkelin institutionaalisen etnografian lähestymistavan, etnografiset aineistot ja aineiston analyysin. Artikkelissa tulosluku muodostuu toimijuuden modaliteettien tarkastelusta. Artikkelin päättää Johtopäätökset ja keskustelu -luku, jossa pohdin kriittisesti työtoiminnan uudistamistarpeita tutkimuksen tulosten ja aiemman tutkimuksen perusteella.

\section{Lähtökohtia toimijuuden vahvistumiseen}

Ymmärrän tässä tutkimuksessa toimijuuden välittäväksi käsitteeksi, joka yhdistää yksilöllisen, sosiaalisen ja yhteiskunnallisen ulottuvuuden toisiinsa (Hoggett 2001, 43, 48; Lister 2004; Sen 1993, 190). Yksilön toi- 
mijuus perustuu paitsi subjektien yksilöllisiin ja kollektiivisiin voimavaroihin ja toimintakykyisyyksiin myös siihen, miten ympäröivät olosuhteet, yhteiskunnan rakenteet ja palveluiden sosiaaliset käytännöt luovat toimintamahdollisuuksia toimintakykyisyyden ja toimijuuden vahvistumiselle (Lister 2004, 126, 128; Nussbaum 2011; Sen 1993). Siinä missä toimintakyvyn käsite viittaa potentiaaliseen kykyisyyteen, määrittyy toimijuus todellisena toimintamahdollisuutena ja toimintana. Klaus Weckroth $(1992,31)$ on kutsunut toimintaa subjektin keskeiseksi olotilaksi, joka voi laajentua myös yhteiseksi me-tilaksi. Toimijuus ei ole pelkästään yksilöllinen vaan relationaalinen kysymys, joka heijastaa osaltaan yhteiskunnan aikakauden vallitsevia käsityksiä ja harjoitettua sosiaalipolitiikkaa (myös Kivipelto \& Saikkonen 2017).

Jyrki Jyrkämä (2008) määrittää toimijuuden dynaamisena prosessina, jossa toimijuus muotoutuu yksilön taustaan, elämänkulkuun ja yhteiskunnallisiin rakenteisiin liittyvistä ajan ja paikan koordinaateista ja tilanteisista modaliteeteista (myös Ronkainen 1999). Toimijuuden modaliteetit muotoutuvat motivaatiosta ja intentionaalisuudesta (haluan), kykenemisistä, erilaisista tiedoista ja taidoista (osaan), välttämättömyyksistä, pakoista ja rajoitteista (minun täytyy), tunteista, arvioista ja arvostuksista (tunnen) sekä mahdollisuuksista ja vaihtoehdoista (voin). Tunteminen ja voiminen ovat yhtäl̈lä toimijuuden eri puolia valottavia ulottuvuuksia ja toisaalta toisiinsa kietoutuva prosessi. Toimijuuden modaliteeteista täytyminen kuvastaa selkeimmin yhteiskunnallista kontrollia ja yksilön vapauden puuttumista (Juvonen 2013, 218). Myös ikä, sukupuoli, sukupolvi, kulttuurinen tausta, ympäristö ja ajankohta vaikuttavat toimijuuden mahdollistumiseen.

Toimijuuden ja työttömyyden dilemma sekä toimijuus palveluissa on innostanut tutkijoita paljon (esim. Elonen, Niemelä \& Saloniemi 2017; Hokkanen 2014; Juvonen 2013; Laitinen \& Niskala 2013; Lähteenmaa 2010; Saikku \& Kokko 2012). Työtä vailla olevia nuoria koskevassa haastattelututkimuksessa Martti Siisiäinen (2014) kuvasi toimijuuden muotoutumista polkujen risteyksenä, jossa asioita tapahtuu myös sattuman johdosta (myös de Certaux 1984). Siisiäisen (2014) tutkimuksessa nuorten suhde hyvinvointivaltion instituutioihin näyttäytyi sekä pakottavana että vapaaehtoisena. Toimijuus ilmentää yhteiskunnallisesti sitä, miten ihmiset voivat käyttää autonomiaansa ja vapauttaan sekä toimia toisin, huolimatta yhteiskunnallisista valtasuhteista (Lister 2004, 126; Ronkainen 1999, 51). Jaan nuorten syrjäytymistä tutkineen Tarja Juvosen (2013, 
101) esittämän näkemyksen siitä, että autonomisuus ja vapaus eivät ole ristiriidassa riippuvuuden ja tarvitsevuuden kanssa, vaan ne edellyttävät toisiaan. Juvosen etsivää työtä tarkastelevassa ja yhteiskunnasta syrjään jäämistä koskevassa tutkimuksessa nuoret pystyivät suhtautumaan yhteiskunnallisiin ehtoihin annettuina, kapinoimaan niitä vastaan tai tulkitsemaan niitä uudelleen. Mahdollisuutena oli myös pyrkiä ulos annetuista ehdoista (Juvonen 2013, 164).

Voimavaraistava ja valtaistava työote ja niiden merkitys toimijuudelle on laajasti tunnistettu ja tunnustettu sosiaalialan työssä ja sosiaalipolitiikassa (esim. Adams 1993; Hokkanen 2014, 122; Lassander, Solin, Tamminen \& Stengård 2013; Ruuskanen, Savolainen \& Suonio 2011; Väisänen 2011). Voima-kantasanasta juontuva voimaantuminen ilmenee erityisesti subjektiivisena kokemuksena ja yksilöllisenä prosessina (Saleebey 2000, 133). Tutkimusten perusteella voimaantumisella on selkeä yhteys palvelujen laatuun ja vaikuttavuuteen (Lassander ym. 2013, 689). Voimaantumisella ja valtaantumisella voidaan tarkoittaa myös yhteisöllistä tai jopa yhteiskunnallista toimintavoimaa sekä voiman ja vallan näkökulmien yhdistymistä (empowerment).

Sosiaalipedagogiikan tavoitteena on edistää ihmisten sosiaalista integroitumista ja osallistumista sekä torjua syrjäytymistä. (Hämäläinen 2015.) Sosiaalipedagogiikassa emansipaation käsite kiinnittää huomion erityisesti ihmisten ja yhteiskunnan välisiin suhteisiin, valtaan ja yhteiskunnan institutionaalisiin rakenteisiin, jotka voivat rajoittaa ihmisten toimintamahdollisuuksia (Ryynänen \& Nivala 2017). Lähtökohtana on laajemmin elämään liittyvä eriarvoisuus ja osattomuus, mikä edellyttää konkreettisia muutoksia yhteisöllisellä ja yhteiskunnallisella tasolla toimintamahdollisuuksien laajentamiseksi. Siinä missä voimaantuminen ilmentää ihmisten toimintakykyisyyksien ja pystyvyyden kehittämistä, jotta ihmiset kykenevät ja voivat toimia olemassa olevissa systeemeissä ja valtasuhteissa, merkitsevät valtaantuminen ja emansipaatio tietoisuuden kasvua sekä olemassa olevien rakenteiden kriittistä analysointia, voima- ja valtasuhteiden haastamista ja sopeuttamisen sijaan autonomisuuden kasvua ja vapautumista. (Hämäläinen 2015, 40-42; Ryynänen \& Nivala 2017; Freire 1972; 2005; Hannula 2000, 40-42, 83; Van Heertum 2006, 45-47, 50). Myös Paul Hoggett (2001) ja Ruth Lister (2004) ovat teoretisoinneissaan huomioineet toimijuuksien transformatiivisen luonteen yhtenä muutoksen mahdollisuutena. Yksilöiden aikaperspektiivi muutokseen on kuitenkin usein lyhyempi kuin yhteisöjen tai yhteiskunnan instituti- 
onaalisten järjestelmien kehittämisessä (Kostilainen \& Nieminen 2018). Sosiaalipedagogiikan kriittisessä suuntauksessa emansipaatio liittyy olennaisesti kysymykseen osattomuudesta ja yhteiskuntaan integroitumisesta, joka ymmärretään yksilöiden, ryhmien ja yhteiskunnan väliseksi vastavuoroiseksi suhteeksi (Hämäläinen 2015).

Brasilialaiselle Paulo Freirelle (1921-1997) toivon pedagogiikka oli määrittävä elementti politiikassa ja vedenjakaja, jossa valtaa ja vallattomuutta tuotetaan ja uusinnetaan (Giroux 2000, 719). Toivo ei merkinnyt Freirelle epärealistista unelmointia vaan todellisia poliittisia pyrkimyksiä tasa-arvoisemman yhteiskunnan aikaansaamiseksi. Se merkitsi äänen antamista niille, jotka elävät hiljaisuuden ja sorron kulttuurissa (Freire 2005). Nyky-yhteiskuntaan ja tutkimuksen maailmaan siirrettynä tämän voi ymmärtää näkökulmaksi ja tilan antamiseksi palvelujärjestelmän asiakkaiden tulkinnoille (esim. Laitinen \& Niskala 2013; Pohjola, Kairala, Lyly \& Niskala 2017). Lisäksi se tarkoittaa aitojen toimintamahdollisuuksien ja myönteisten siirtymien luomista ihmisille ja niiden näkemistä, jotta ihmisillä säilyy esimerkiksi toivo toimintakyvyn vahvistumisesta ja luottamus palveluprosesseihin (Kostilainen \& Nieminen 2018, 23). Hyvinvointivaltio eli palvelut, tulonsiirrot sekä työntekijöiden antama tuki ja apu ymmärretään yhteiskunnallisina toimintamahdollisuuksina, jotka mahdollistavat toimijuutta. Joka yhteiskunnassa on Freiren nimeämää sortoa, rakenteellisia epätasa-arvoisuuksia, jotka systemaattisesti estävät ihmisiä ja yhteisöjä toteuttamasta elämänsuunnitelmiaan.

\section{Tutkimuksen toteutus}

Tämän artikkelin empiirisen tutkimuksen aineistot perustuvat etnografiseen kenttätyöhön, jonka tein vuosina 2015 ja 2016 kahdeksan kuukauden aikana. Artikkelin aineistona on 37 kuntouttavaan työtoimintaan osallistujan haastattelua ja osallistuvan havainnoinnin tuottama kenttätyöpäiväkirja-aineisto (yhteensä 776 tekstisivua). Tarkemmin ottaen kiinnityn tutkimuksessani institutionaaliseen etnografiaan. Se kehittyi tarpeesta tehdä tutkimusta, joka alkaa arjen kokemuksista ja sosiokulttuurisesta todellisuudesta ja päätyy analysoimaan palveluita, sosiaalisia käytäntöjä ja harjoitettua politiikkaa (Campbell \& Gregor 2004; Hietala 2013; Jokela 2011; Smith 1987; 2005; 2006; Suoranta \& Ryynänen 2014, 264-272). Tässä tutkimuksessa etnografian institutionaalisuus ilmenee haluna analysoida työtoimintaan osallistuvien elämäntilanteiden, tavoitteiden ja toiveiden sekä palvelujärjestelmän ja harjoitetun politiikan suhdetta. Yksilöl- 
liset kokemukset ja työtoiminnalle annetut merkitykset paitsi heijastavat yhteiskunnallisia olosuhteita myös esiintuovat toisin toimimisen tarpeita yhteiskunnallisen tasa-arvoisuuden ja oikeudenmukaisuuden näkökulmasta.

Tutkimusaineistot kerättiin kenttätyön aikana kolmessa työtoiminnan yksikössä kolmessa eteläisen Suomen kaupungissa. Työtoiminnan yksiköiden työtoiminnan sisällöt olivat vaihtelevia. Joukossa oli lounaskahvila, atk-laitteiden korjaus ja huolto sekä puu- ja pintakäsittely-yksikkö. Aineiston keruu alkoi syksyn 2015 aikana ja päättyi toukokuussa 2016. Tutkimuksen toteutusta edelsivät hyvän tieteellisen käytännön mukaisesti kaupunkien tutkimuslupamenettelyt sekä tutkimuksen toteutuksen ja tavoitteiden informointi työyksiköille, työntekijöille ja osallistujille. Tutkimuksen toteutus perustui osallistujien vapaaehtoisuuteen, kirjallisiin suostumuksiin ja tiedonsaantiin tutkimuksesta. Aloitin kenttätyön vaiheittain sitä mukaa, kun sain myönteiset tutkimuslupapäätökset ja luvan aloittaa tutkimustyön yksiköissä.

Aineistonkeruu pohjautui vuorovaikutukseen sekä työtoimintaan osallistujien että työntekijöiden kanssa. Pääsin oppimaan työtoiminnan käytännöistä osallistuvan havainnoinnin avulla (Hammersley \& Atkinson 2007, 79-80). Läsnäoloni yhdessä yksikössä vaihteli pääsääntöisesti yhdestä kahteen kertaan viikossa, kerrallaan yhdestä neljään tuntia. Ajallisesti kentällä olon ja sieltä poissaolon jaksot vuorottelivat. Olin tutkijana työtoiminnan arjessa, keskustelin osallistujien ja työntekijöiden kanssa, kuuntelin, toimin joskus apuna työtoiminnan tehtävissä ja haastattelin osallistujia. Toisinaan olin sivummalla ja kirjoitin kannettavalle tietokoneelle muistiinpanoja siitä, mitä työtoiminnassa tapahtuu. Työtoiminnan yksiköt erosivat toisistaan paitsi toiminnan sisällöiltään myös toimintatavoiltaan ja fyysisinä tiloina, mikä vaikutti osaltaan kenttätyön toteutukseen. Yhdessä yksikössä osallistujien joukko ja tilat olivat pienehköt. Siellä roolini oli erityisen vuorovaikutteinen ja kirjoitin lyhyitä muistiinpanoja ainoastaan vihkooni, josta myöhemmin tallensin havainnot tietokoneelle. Lähestymistapanani oli olla kuitenkin vaikuttamatta työtoiminnan tapahtumien kulkuun ja välttää tarpeettomia keskeytyksiä. Yhteisen pöydän äärellä vietetyt tauot osoittautuivat myös tärkeiksi hetkiksi tutkimuksen kannalta, kun osallistujat kertoivat kokemuksistaan ja keskustelivat ajankohtaisista asioista.

Osallistuvassa havainnoinnissa huomioni kiinnittyi erityisesti siihen, mitä työtoiminnassa tapahtuu ja millainen on kuntouttava työtoiminta 
sosiaalisina käytäntöinä (Hammersley \& Atkinson 2007, 200; Shove ym. 2012). Sovelsin kenttätyössä Spradleyn (1979) havainnoinnin jäsennystä, jonka perusteella tein huomioita tilasta, toimijoista, toiminnoista kentillä, materiaaleista, ajasta, tavoitteista ja tunteista. Havainnointia sekä haastattelujen toteutusta ohjasivat myös tutkimuksen kysymyksenasettelu sekä tutkimusta orientoivat käsitteet. Haastattelujen ja havaintojen lisäksi, koin tutkimusprosessin kannalta olennaiseksi myös kenttätyön aikana tekemäni reflektoinnin ja sen myötä kasvaneen ymmärryksen karttumisen tarkasteltavasta ilmiöstä. Etnografisen tutkimuksen erottaa muista laadullisen tutkimuksen perinteistä fyysinen läsnäolo (esim. Merleau-Ponty 2012) samoin kun etnografisen tutkimuksen pitkittäisesti muodostuva tietämys. Etnografiassa kenttätyö ja aineiston kartuttaminen on siten moniaistista ja kokonaisvaltaisempaa kuin aineistonkeruu tiettyä menetelmää käyttäen. Keskustelut työntekijöiden kanssa ja kenttätyön aikana kerätyt kirjalliset dokumentit taustoittivat tutkimuksen tekoa.

Tutkimusprosessin aikana tekemäni haastattelut toteutuivat kussakin työtoiminnan yksikössä useimmiten erikseen haastatteluja varten varatussa tilassa. Keskeiset haastatteluteemat liittyivät työtoiminnan sisältöön, merkityksiin, konkreettisiin muutoksiin, toimintamahdollisuuksiin, toisin toimimisen tarpeisiin ja lähitulevaisuuden suunnitelmiin. Nauhoitin haastatteluista 34 sekä toisinaan eripituisia pätkiä keskusteluista työtoiminnan arjessa. Sain litterointiin tutkimusapua, joten litteroin nauhoituksista itse vain osan. Kolme haastattelua kirjoitin tekstimuotoon käsinkirjoitettujen muistiinpanojen perusteella. Aineiston käsittelyssä, analysoinnissa ja tulosten raportoinnissa olen poistanut osallistujia ja työtoiminnan yksiköitä koskevat tunnistetiedot ja merkinnyt tässä artikkelissa käyttämäni haastatteluaineisto-otteet numeroinneilla. Olen kuvannut tutkimuksen toteutusta, eettisiä kysymyksiä ja tutkijan positiotani myös aiemmissa osatutkimuksissa (Mäntyneva \& Hiilamo 2018; Mäntyneva \& Isola 2019).

\section{Analyysin eteneminen}

Aineisto analysoitiin teoriaohjaavalla sisällönanalyysilla, mikä etnografisessa tutkimuksessa käynnistyy jo kenttätyön alettua (esim. Coffey \& Atkinson 1996, 11). Esiymmärryksenä tämän tutkimuksen aineiston analysoinnissa olivat paitsi tutkimuskysymykset myös ymmärrys toimijuudesta aiemman tutkimustiedon pohjalta. Keskeisenä teoreettisena kehyksenä analyysissa toimi Jyrki Jyrkämän (2008) toimijuuden modaliteettien jä- 
sennys. Semiotiikassa eli tekstien merkitysmaailman tutkimisessa sekä semioottisessa sosiologiassa modaliteettiteoriaa on sovellettu mahdollisten maailmojen ja toisaalta yhteiskunnallisten reunaehtojen tutkimuksessa. Jyrkämä (2008, 196-197) on edelleen kehitellyt modaliteettiteoriaa toimijuuden tutkimiseksi. Hänen ajattelunsa on saanut vaikutteita semiotiikan ja Greimasin koulukunnan ohella elämänkulkututkimuksesta (esim. Elder \& Johnson 2003) sekä Giddensin strukturaarioteoriasta (Giddens 1984). Toimijuuden analysoimiseksi modaliteettiajattelua ovat soveltaneet esimerkiksi nuorisotyöttömyyteen ja työvoimapolitiikkaan liittyvässä tutkimuksessa Jaana Lähteenmaa (2010) sekä Paltamon työllisyyskokeilun arviointitutkimuksessa Peppi Saikku ja Riitta-Liisa Kokko (2012). Myös Tarja Juvonen (2013) analysoi väitöskirjatutkimuksessaan nuorten toimijuuden modaliteetteja.

Aineiston analysointi alkoi koko aineiston lukemisella. Etsin aineistosta ilmauksia toimijuuden modaliteettien eri ulottuvuuksilta: haluta, osata, kyetä, täytyä, voida, tuntea. Luokittelun apuna käytin ATLAS.ti-ohjelmaa, mikä osoittautui aineiston hallinnan kannalta olennaiseksi. Modaliteetteihin liittyvien ilmaisujen löytymiseksi muodostin erilaisia hakusanoja ja sanojen lyhenteitä. Haluta ulottuvuuden osalta käytin esimerkiksi lyhenteitä tavoi ${ }^{\star}$, päämä ${ }^{\star}$ ja motiv ${ }^{\star}$ ja täytyä ulottuvuuden osalta hakusanoina olivat esimerkiksi pakko, välttäm ${ }^{\star}$, est ${ }^{\star}$, rajoi $^{\star}$, pakot. Säilytin ilmaukset kuitenkin asiayhteyksissään siten, että aineistosta erotettiin ilmauksiin myös niihin liittyvät lauseet ja tekstin osat. Tämän jälkeen muodostin saadusta aineistosta yhtenäisen tekstidokumentin ja luokittelin aineistoa poimimalla pelkistyksiä kustakin modaliteettiverbin ulottuvuudesta. Analyysin toisessa vaiheessa luin aineistoa useampaan kertaan, jolloin siitä alkoi hahmottua kutakin toimijuuden vahvistumista ja modaliteettiverbiä koskevia teemoja. Muodostuneet teemat ovat: 1) motivaatio, 2) toimintakyvyt, 3) toimintavalmiudet, 4) arvostukset, 5) reflektio ja 6) myönteinen tulevaisuushorisontti. Olen koonnut teemat taulukkoon 1. 
Taulukko 1. Toimijuuden vahvistumiseen liittyvät teemat aineistossa Jyrkämän (2008) modaliteettiteorian kehittelyä mukaillen

\begin{tabular}{|c|c|c|c|}
\hline TEEMAT & $\begin{array}{l}\text { MODALITEETTI- } \\
\text { VERBIT }\end{array}$ & HAKUSANAT & $\begin{array}{l}\text { ESIMERKKI- } \\
\text { ILMAUKSET }\end{array}$ \\
\hline Motivaatio & Haluta & $\begin{array}{l}\text { Tavoi(te), } \\
\text { päämä(ärä), } \\
\text { moti(vaatio) }\end{array}$ & $\begin{array}{l}\text { "Jos motivaatio on kohillaan, niin } \\
\text { kyllä tää varmaan voi edistää hyvinkin } \\
\text { pitkälle" } \\
\text { "Näkee tän motivaation itsessään ja } \\
\text { haluaa oppia", } \\
\text { "Mä haluaisin tehdä jonkun oikeesti } \\
\text { loppuun, saada jotain näyttöö } \\
\text { osaamisesta ja jatkaa siitä kouluun." }\end{array}$ \\
\hline $\begin{array}{l}\text { Toiminta- } \\
\text { kyvyt }\end{array}$ & Kyetä & $\begin{array}{l}\text { Pystyy, } \\
\text { jaksaa, } \\
\text { jaksa* }\end{array}$ & $\begin{array}{l}\text { "Saa omaa fyysistä kuntoo parannettua } \\
\text { ja sit on myös jotain keskusteluryhmiä, } \\
\text { mihin on mahollisuus osallistua". } \\
\text { "Et saa henkistä puolta vahvistettua." } \\
\text { Saa semmosta tervettä itsetuntoo ja } \\
\text { tuntuu, että sitte, ku tulee kotiinkin ni } \\
\text { jaksaa enemmän tehä." }\end{array}$ \\
\hline $\begin{array}{l}\text { Toiminta- } \\
\text { valmiudet }\end{array}$ & Osata & $\begin{array}{l}\text { Osaa, } \\
\text { taido(t), } \\
\text { tie(dot) }\end{array}$ & $\begin{array}{l}\text { "No joku meistä tekee sen, kuka kerkeää } \\
\text { ja pystyy ja osaa." } \\
\text { "Osaan laittaa ruokaa." } \\
\text { "Vähä sosiaaliset taidot kasvaa tässä, } \\
\text { että sitä ku on aika yksinäine ihminen." }\end{array}$ \\
\hline Arvostukset & Tuntea & $\begin{array}{l}\text { Tunne, } \\
\text { tunte(et), } \\
\text { arvos(tus), } \\
\text { arvio }\end{array}$ & $\begin{array}{l}\text { "Mä oon arvostanu sitä hyvää ilmapiirii." } \\
\text { "Mä arvostan tätä, että kierrätetään." } \\
\text { "Monet ihmiset on hyvin ilahtuneita sii- } \\
\text { tä, että niitten työtä arvostetaan." }\end{array}$ \\
\hline Reflektio & Täytyä & $\begin{array}{l}\text { Pakko, } \\
\text { välttäm*, } \\
\text { rajoi*, } \\
\text { pakot* }^{*}\end{array}$ & $\begin{array}{l}\text { "Tää kasvattaa vaa eriarvoistumista", } \\
\text { "Nää on niin sanotusti rappusia, mitkä on } \\
\text { pakko tehä jossain vaiheessa." } \\
\text { "Tänne pakotetaan ihmisiä, jotka ei halua } \\
\text { ja ne jotka, haluaa, ne pakotetaan pois." } \\
\text { "Me ollaan opetettu niille, en mä tiedä } \\
\text { kuinka monta vuotta, että se on sallittua } \\
\text { ottaa ilmatteeks työvoimaa." }\end{array}$ \\
\hline $\begin{array}{l}\text { Myönteinen } \\
\text { tulevaisuus- } \\
\text { horisontti }\end{array}$ & Voida & $\begin{array}{l}\text { Voi, } \\
\text { mahdoll* }\end{array}$ & $\begin{array}{l}\text { "Kyl mä voin saada viel ammatinki } \\
\text { ja kehittyä ihmisenä ja osaajana ja } \\
\text { ammattilaisena... } \\
\text { "Ainoa mahdollisuus on työllistyä } \\
\text { kaupungille palkkatukityöhön" } \\
\text { "Täältä voin saada osaamistodistuksen." }\end{array}$ \\
\hline
\end{tabular}


Kuvaan seuraavassa luvussa, miten toimijuus voi vahvistua kuntouttavassa työtoiminnassa. Voimaantumista tai toimijuuden tarkastelua ei voi irrottaa kontekstista tai toimijoista. Siten myös tutkimustulokset ovat tulkittavissa suhteessa tarkasteltuun sosiokulttuuriseen todellisuuteen, toimijoihin, sosiaalisiin käytäntöihin ja institutionaalisiin suhteisiin kuntouttavassa työtoiminnassa (Jyrkämä 2008). Motivaatio-ulottuvuus ja päämäärälähtöisyys liittyvät läheisesti tulevaisuushorisontteihin, siksi niitä tarkastellaan yhdessä. Ulottuvuuksista tunteet limittyivät kaikkein kiinteimmin kaikkiin modaalisiin ulottuvuuksiin.

\section{Tutkimuksen tulokset}

\section{Toimintakyvyt ja -valmiudet}

Toimintakykyjen lisääntyminen ilmenee aineistossa osallistujan kokemuksena pystyvyydestä ja lisääntyneinä voimavaroina. Säännöllistynyt arkirytmi on yksi usein mainituista kykeneväisyyksistä, joka on muuttunut elämässä työtoimintaan osallistumisen myötä. Oma epävarmuus ja pelot hälvenevät, kun osallistuja saa onnistumisen kokemuksia siitä, että kykenee, jaksaa ja innostuu. Joillekin yksistään osallistuminen työtoimintaan lisää voimavaroja, mikä ilmenee esimerkiksi kokemuksena itsetunnon kasvusta. Työtoiminnan jatkuessa kolmen kuukauden jakson jälkeen voidaan elämäntilanne huomioiden osallistumispäiviä lisätä maksimissaan neljään osallistumispäivään viikossa. Suhdetta työntekijään ja palvelujärjestelmään yksi kuntouttavaan työtoimintaan osallistuja kuvaa vastavuoroiseksi:

Jos ei oo ite valmis kantamaan vastuuta mistään, ni kyllä se näkyy myös sillon viranomaisten toiminnassakin, mut jos ite on valmis kantamaan vastuuta omista asioistaan, ni kyl viranomaiset tukee mun mielestä aika hyvin. (Haastattelu 14)

Aineistossa toimintavalmiuksien kasvu esiintyy osallistujien kokemuksissa osaamisen vahvistumisena ja kykynä tarttua asioihin myös oma-aloitteisesti. Vailla ammatillista koulutusta olevien osalta työtoiminnan jaksolta saatava osaamisen näyttö voi olla apuna koulutukseen hakeutumisessa. Osaamistodistus voi toimia osasuorituksena opinnoissa. Parhaimmillaan kuntouttavan työtoiminnan tehtäviä suunnataan kiinnostusten mukaan siten, että vähitellen osallistujat voivat tehdä monimutkaisempia tehtäviä 
ja voivat halutessaan käyttää luovuuttaan esimerkiksi uusien tuotteiden tekemisessä. Toivon pilkahduksia osallistujien elämään tuo työtoiminnassa esimerkiksi se, että yksinhuoltajana voi yhdistää perhe- ja työelämän kuntouttavan työtoiminnan avulla. Yksi osallistuja mainitsee kykenevänsä hoitamaan lastaan koulupäivän jälkeen, kun aamuvuoro työtoiminnassa päättyy. Eräs osallistuja kertoo taasen siitä, miten erityistä tukea tarvitsevan lapsen asioiden hoitoon ja selvittelyyn jää enemmän voimavaroja ja aikaa, kun ei ole palkkatyössä. Tyypillistä työtoimintaan osallistujille on, että aikaa palkkatyöhön osallistumisesta on kulunut kauan. Erään nuoren kohdalla tilanne on toisenlainen: nuori ei ole vielä saanut edes ensimmäistä työpaikkaa valmistumisen jälkeen, ja työpaikan korvikkeeksi on tarjottu kuntouttavaa työtoimintaa. Poikkeuksen aineistossa tekee yksi työtoimintaan osallistuja, joka on ollut hiljattain työelämässä. Hän kertoo voivansa paremmin nyt kuin palkkatyössä, kun ei tarvitse jatkuvasti stressata, miten provisiopalkkaisella työllä tulee toimeen.

\section{Reflektio}

Kuntouttavaan työtoimintaan osallistujat kertovat työtoimintaan liittyvistä täytymisistä ja pakoista. Kun osallistuja kertoo kokemuksistaan ja kokemastaan epäoikeudenmukaisuudesta, yksilö voi oman tilanteensa tiedostaessaan ja kokemuksiaan sanoittaessaan voimaantua ja valtaantua. Sopimuksellisuus on keskeinen elementti osana kuntouttavaa työtoimintaa. Keskustelu jaksoista, niiden alkamisista ja päättymisistä sekä työtoiminnan päivistä ja tunneista oli työtoiminnan kentillä päivittäistä. Siitä huolimatta työtoimintaan osallistujat eivät juurikaan puhuneet aktivointisuunnitelmista vastuullisuuden tai velvoittavuuden näkökulmasta. Voimavaraistavaan työotteeseen voi liittyä elämäntapoihin liittyvää kontrollia sosiaalisen työn näkökulmasta. Tämän tutkimuksen työtoiminnan kentillä se oli vähäistä tai se ei käynyt ilmi: yhden osallistujan kohdalla edellytyksenä työtoimintaan osallistumiselle oli vertaisryhmään osallistuminen päihdekuntoutumisen tueksi. Yhdellä työtoiminnan kentistä työskenteli terveysneuvoja, jonka tehtävänä oli ohjata pitkäaikaistyöttömiä terveellisten elämäntapojen äärelle. Kuntouttavaan työtoimintaan osallistuvilla oli mahdollisuus osallistua liikuntaryhmiin. Monet osallistujat paitsi kertoivat omasta tilanteestaan puhuivat myös yleisemmin työttömistä tai aktiivipalveluihin ja kuntouttavaan työtoimintaan osallistujista. Siten he ottivat yhteiskunnallisesti kantaa koskien suurempaa joukkoa samassa tilanteessa olevia ihmisiä, kollektiivisina toimijoina (vrt. Hokkanen 2014). 
Näin tietoisuus laajentuu oman elämäntilanteen ulkopuolelle asettumiseen, yhteiskunnallisten olosuhteiden tiedostamiseen ja kokemusten sanoittamiseen.

Osallistujien kokemuksissa työtoiminnassa toimimisen tarpeet kytkeytyvät mielekkääseen tekemiseen, läsnä olevaan ammattitaitoiseen ohjaukseen, toiminnan vapaaehtoisuuteen, työtoiminnan jatkuvuuteen tai jatkopolkuihin sekä toiveisiin saada palkkatyötä tai palkkatukityötä. Lisäksi osallistujat mainitsivat toivovansa elämässään toimintamahdollisuuksia harrastus- ja vapaa-ajan toimintaan kuten vesijuoksuun sekä yhteiskunnalta reiluutta työtoiminnasta saatavaan korvaukseen tai työttömyyskorvauksen kompensoimista verotuksessa. Lisäksi haastateltavat ehdottivat kohtaamisia työantajien kanssa ja työtoiminnassa tehtävien tuotteiden omistajuutta sekä mahdollisuutta muodostaa osuuskuntamallista toimintaa työtoiminnan ympärille silloin, kun ammattitaito ei ole työllistymisen esteenä. Etenkin vieraskielisten kuntouttavaan työtoimintaan osallistujien kohdalla herää myös kysymys siitä, tarjotaanko kuntouttavaa työtoimintaa vaihtoehdoksi, kun palkkatyötä ei vaan löydy esimerkiksi kielitaitoon tai matalaan koulutustasoon vedoten. Kielikurssille osallistuminen osana työtoimintaa on ollut yksi väylä kielitaidon kohentamiseksi. Työtoiminnassa koetut täytymiset ja pakot voivat muuntua ajan kuluessa mahdollisuuksiksi voimavarojen lisääntyessä:

Jotenki, ku mä pystyin yhtäkkii tekee semmosii päätöksii, mitä oli pakko tehä ja mitä mä en jotenki ollu osannu mukamas tehä, mut sitte ne ei enää tuntunukaan yhtään pahalt, vaan ne tuntu helpottavalt ja vapauttavalta. (Haastattelu 27)

Niukkuusteoria selittää ilmiötä sillä, että keskittyessään puutteeseen, kuten arvottomuuteen, kiireeseen tai rahattomuuteen, ihminen joutuu vaihtoehdottomuuden tilaan ja alkaa elää lyhytjänteistä aikaa, jolloin olemassa olevia toimintakykyjä ja yhteiskunnan tarjoamia mahdollisuuksia jää käyttämättä (Mullainathan \& Shafir 2013). Outi Hietala $(2018,132)$ kertoo, että vaikka kuntoutuminen edellyttää luottamusta omiin voimavaroihin ja mahdollisuuksiin, voi toivo hautautua joskus näköalattomuuteen ja epäonnistumisen pelkoihin. Tämän korjaaminen voi viedä aikaa ja vaatia ammattilaiselta kiireetöntä kykyä kohdata tunne-energiaa sitovat kokemukset. Toisaalta ihmisten elämäntilanteet muuttuvat ja kuntoutumisen prosessit voivat olla joskus yllättäviäkin. Moni osallistuja koki va- 
paaehtoisuuden ja autonomisuuden kokemuksen tärkeäksi elementiksi työtoiminnassa, kuten eräs työtoimintaan jo useamman jakson ajan osallistunut nuori aikuinen kertoo:

Mun mielestä jokaisen pitäis antaa kulkea omat polkunsa, eikä yrittää liimata tiettyyn muottiin. Kun jokainen meistä on kuitenkin erilainen... Mun mielestä jokaiselle pitäis antaa, siis eläimelle, ihmiselle, luonnolle, kaikelle pitää antaa se mahdollisuus valita minun mielestäni, et sä voit kokeilla tätä, et jos ei se sovi niin ok kokeile toista. Eikä se että tää on pakko käydä sulle tai sä oot työtön. Se on mun mielestä väärin. (Kenttätyömuistiinpanot 369)

\section{Arvostukset}

Toimijuuden vahvistumisen kannalta ei ole merkityksetöntä, millaisia tunteita kuntouttava työtoiminta herättää. Aineiston analysoinnin perusteella työtoiminta aikaansaa iloa, innostusta, arvostusta, kunnioitusta, hyväksyntää, luottamusta sekä toiveikkuutta elämään. Toisaalta se aiheuttaa huolta, surua, vihaa sekä häpeän tunteita. Myönteiset tunnekokemukset ja arvostus lisäsivät tutkimuksen perusteella osallistujien toimijuutta ja voimaantumisen kokemuksia. Kokemukset siitä, että tulee hyväksytyksi omana itsenään, arvostetuksi ja kohdelluksi tasavertaisesti, vahvistavat voimavaroja, kykyuskomuksia ja pystyvyyden tunnetta (vrt. Siitonen 1999; Honneth 1995, 109). Hyväksyntä ja keskinäinen arvostus heijastuvat ilmapiiriin myönteisesti.

Kun pääsee pois sielt kotoo, pääsee johonki ympäristöön, missä ollaan tasavertaisia ja on mielekästä tekemistä niin se vaikuttaa ihan älyttömän paljon muuhunki jaksamiseen ja hyvinvointiin. Rupee jotenki näkee asiat ihan uudessa valossa. Jotenki tuntuu, et mittasuhteet on taas paljon enemmän oikein koko henkilökohtasessaki...Sit on nähny muitakin tosi hienoja tarinoita muis ihmisissä, et miten ne on muuttuneet ja saaneet elämäänsä otetta ja saaneet itsevarmuutta ja keikennäköst osaamista ja just semmonen tää onnistumisen kokemus. (Haastattelu 32)

Työtoimintaan osallistumisen myötä oma kokemuspiiri ja osalla sosiaalisten suhteiden piiri laventuvat. Moni kuntouttavaan työtoimintaan osallistuvista asuu ja elää yksin. Jotkut heistä kokevat yksinäisyyttä. Oma elämäntilanne voi asettua uuteen valoon työtoimintaan osallistumisen 
myötä ja osana arvostavia vuorovaikutussuhteita. Kun näkee ympärillä onnistumisen tarinoita ja myönteisiä liikahduksia elämäntilanteissa, lisää se uskoa tulevaisuuteen sekä itseen ja omiin mahdollisuuksiin. Työtoiminnassa toimiminen pareittain ja ryhmissä vahvistaa kokemuksia jaetusta toimijuudesta, jossa saavutetaan yhteisiä päämääriä kollektiivisesti. Tutkimuksen perusteella se, että työtön identifioi itsensä kuntoutujaksi, lisää osallistumisen myönteistä merkitystä. Toisaalta kaikki eivät koe kuntouttavan työtoiminnan osallistujien ryhmää itselleen merkitykselliseksi arvoyhteisöksi, johon haluttaisiin kuulua. Vastaavasti, jos työtoiminta koetaan loukkaavana, ilmaistyönä, ajan kuluttamisena ja toimettomuuden tilana, sinnittelynä pienen toimeentulon takia ja työttömien nöyryyttämisenä, heijastuu se koko toimijuuteen kielteisesti. Esimerkiksi toistuva vuorottelu työttömyyden ja aktiivipalveluiden välillä vaikuttaa identiteettiin:

Nii et siinä kokee ihan häpeen tunnetta siitä että, et se ei oo niinkun semmonen ilonen asia, että tänne tulee...Tuntee ittensä niinku tosi turhautuneeks ja semmoseks niinku et miks mä oon ees täällä’. Siinä tuntee surua ja turhautumista, että joutuu takaisin siihen tilanteeseen, että on työtön. Niin kyllähän se on aika, jotenki tuntuu, että on semmonen leima ottassa. (Haastattelu 3)

\section{Motivaatio ja myönteiset tulevaisuushorisontit}

Tutkimuksen tulosten perusteella suurin ristiriita toimijuuden vahvistumisen ja valtaantumisen näkökulmasta liittyy siihen, perustuuko työtoimintaan osallistuminen omaan valintaan vai onko se pakon sanelemaa. Motivoitumiseen ja sitoutumiseen vaikuttaa myös se, onko kuntouttavaan työtoimintaan osallistumisen myötä osallistujan näköpiirissä myönteistä tulevaisuushorisonttia vai uupuuko se. Aikomukset ja lähitulevaisuuden suunnitelmat antavat merkitystä osallistumiselle, voimaannuttavat ja luovat tilaa emansipaatiolle ja valtaantumisen kokemuksille:

Mä haluisin mennä kouluun ja mä haluisin saada jonkun ammatin. Ihan ajattelen nyt jotain tälläst perusmaalaripintakäsittelyn tutkintoo. Tavoitteena olis, että vielä olis ammatti. (Haastattelu 17)

Työtoiminnan myönteiset horisontit liittyvät erityisesti koulutukseen hakeutumiseen etenkin, jos osallistujalla ei ole peruskoulun jälkeistä kou- 
lutusta. Myös pääsy palkkatuettuun työhön tai työkokeiluun näyttäytyvät mahdollisuutena. Yksi korkeakoulutettu kuntouttavaan työtoimintaan osallistuja suunnittelee yritystoiminnan perustamista pitkän ulkomailla olon jälkeen. Työtoimintaan sitoutuminen ja motivoituminen ovat vaakalaudalla, kun työttömyyden ja aktivointitoimien vuorottelu toistuu vastentahtoisesti. Osaamispolun vahvistuminen on yksi reitti valoisempiin tulevaisuuden näkymiin, kuten yksi osallistujista sanoo:

Mulle kerrottiin, että nyt on muuttunu tää kuntouttava työtoiminta todella positiiviseen suuntaan. Ennen tää ei ollu mitään semmosta virallista. Siit ei saanu mitään todistusta mihinkään. Ei sitä oikein noteerattu, vaiko ois vaikka kouluun pyrkiny, et mä oon ollu tämmöses näin. Se on vähän, et no joo, että se nyt on niiku vähän semmost harrastust tai semmost. Se tuntuu hyvältä ja tosi iso harppaus siihen, että tää ei oo vaan semmosta ajan tappamista työttömille. (Haastattelu 14)

Toimijuuden vahvistumisen näkökulmasta työtoimintaan osallistujien elämäntilanteet ovat nykyhetkessä niin haastavia, että nykyisen elämäntilanteen ylläpitäminen on jo sinällään suuri tehtävä. Kun elämä on päivä kerrallaan selviytymistä, on kuntouttavan työtoiminnan jaksojen ketjuttaminen pisimmilläänkin lyhyt aika muutokseen. Yhteiskunnalliset odotukset ja pyrkimykset myönteisiin siirtymiin, kuten ammatilliseen koulutukseen hakeutumiseen, voivat siten tapahtua yksilöiden näkökulmasta liian nopeasti, kuten tämän työtoimintaan osallistujan elämäntilanteessa:

En mä uskalla vielä. Mä en oo nïn toipunu tai kuntoutunu... Se on vaan kurja välillä, ku tulee takapakkia... Ei saa luovuttaa kuitenkaan siitä, että mitä on saanu aikaseks. (Haastattelu 35)

Toimijuuden vahvistumisen näkökulmasta palkkatyöhön pyrkiminen tai koulutukseen hakeminen voi olla täysin toissijaista. Osalle ne eivät ole nykyisessä elämäntilanteessa edes toivottuja toimintamahdollisuuksia. Tärkeintä voi olla vähissä olevien voimavarojen kartuttaminen ja ehkä vain nykyisen elämäntilanteen ylläpitäminen. Eikö työtoiminnan tarkoituksena pitäisi olla se, että ihmiset eheytyvät eikä niinkään työtoiminnan tuotteet, kuten yksi työtoiminnan osallistujista sanoittaa. 


\section{Johtopäätökset ja keskustelu}

Kysyin tässä institutionaaliseen etnografiseen aineistoon pohjautuvassa artikkelissa, miten toimijuus voi vahvistua kuntouttavassa työtoiminnassa. Pohdin myös sitä, millaisia reunaehtoja toimijuuden vahvistamiseen liittyy. Analyysin pohjalta nimesin nämä ulottuvuudet motivaatioksi, toimintakykyisyydeksi, toimintavalmiuksiksi, arvostuksiksi (tunteet), reflektioksi sekä myönteisiksi tulevaisuushorisonteiksi. Tutkimuksen tuloksista voi tehdä yleisluontoisen johtopäätöksen siitä, että kysymys toimijuudesta kytkeytyy erityisesti motivaatioon ja päämäärälähtöisyyteen sekä myönteisiin tulevaisuushorisontteihin. Kun ihminen kokee tulleensa työtoimintaan omaehtoisesti, hän kokee voivansa "suunnitella omaa elämäänsä" ja näkee myönteisiä näköaloja paitsi työtoiminnassa olemiseen ja toimimiseen myös työtoiminnan jälkeiseen aikaan. Valtakunnallisesti tarkasteltuna kuntouttavan työtoiminnan keskeyttää tai siitä kieltäytyy noin kuudesosa (Virtanen 2017). THL:n tilastoraportin mukaan keskeinen syy (45 prosentilla) kuntouttavasta työtoiminnasta kieltäytymiseen on motivoitumisen puute palvelua kohtaan (Virtanen 2017). Pääkaupunkiseudulla työtoiminnan keskeyttäneitä on ollut miltei puolet sen aloittaneista (Karjalainen \& Karjalainen 2010). Tämän tutkimuksen perusteella voi ehdottaa, että osallistujien taustoihin ja motivaatioon sekä yksilöllisiin tuen ja avun tarpeisiin kiinnitettäisiin nykyistä enemmän huomiota. Motivoitumisen ja kiinnostuksen heräämisen merkitys myönteisten muutosten syntymiseksi tuli esille myös Siisiäisen (2014) työttömiä nuoria koskevassa tutkimuksessa.

Pitkäaikaistyöttömät ja osatyökykyiset kokevat arvottomuuden kokemuksia (Isola \& Siukola 2017). Tämän tutkimuksen tuloksista on mahdollista tehdä johtopäätös, että toimijuuden vahvistuminen liittyy myös osallistujien arvostuksiin, myönteisiin tunnekokemuksiin ja siihen, että työtoimintaan osallistuja tulee nähdyksi ja kuulluksi sekä kohdatuksi omana itsenään (vrt. Honneth 2012; Kallio, Korkiamäki \& Häkli 2015; Kuure 2015; Taylor 1992). Tietynlainen näkymättömyys palvelussa, henkilökunnan kiire ja dokumentaatiokeskeiset rutiinit sekä asenteet heikentävät osaltaan tunnustetuksi tulemista (Pirhonen 2017). Työtoiminnan kuntoutuksellisuus liittyy siten sanan kuntoutus etymologiaan "arvon palauttamisesta". Huolimatta jokaisen jakamattomasta ihmisarvosta, ovat itsearvostus sekä tunnistetuksi ja tunnustetuksi tuleminen voineet huveta elämänkulkuun liittyvien kokemusten perusteella ja työttömyyden kielteisten seurausten takia (ks. Järvikoski 2013). Toimijuuden vahvistumista tukee välittävä ja arvostava toimintakulttuuri. 
Työtoiminnan kentillä työtoimintaan osallistujien puheen pakoista ja täytymisistä voi tulkita toimijuuden vahvistumiseksi ja Freiren (2005) tavoin kriittiseksi tiedostamiseksi (myös Hoggett 2001; Lister 2004). Käytännössä reflektio tarkoitti tässä tutkimuksessa omien kokemusten ja yleisemmin työttömien yhteiskunnallisen tilanteen sanoittamista ja jäsentämistä ja myös kielteisistä tunteista puhumista. Koettu kontrolli sekä kielteiset tunnekokemukset viestittävät osaltaan toimijuuden kutistumisesta, kun nykyinen elämäntilanne koetaan stressaavana tai asiakkuus palvelujärjestelmässä koetaan leimaavana ja elämäntilanne aiheuttaa kärsimystä (Frost \& Hogget 2008). Osalle kuntouttavan työtoiminnan jaksojen ketjuttaminen vaikeissa elämäntilanteissa ja tarvittavan tuen saaminen voivat osoittautua liian lyhyeksi vaiheeksi toimijuuden vahvistumisen kannalta. Toisaalta kuntouttavan työtoiminnan osallistujista enemmistön kohdalla voi kysyä, palveleeko kuntouttava työtoiminta ennemmin työttömyyden yhteiskunnallista hallintaa kuin työttömien arjenhallinnan tukemista aiheuttaen näkyviä tai hienovaraisempia leimoja asiakkaissa (vrt. Pohjola 2017, 209).

Tässä tutkimuksessa lupaavimmat myönteiset tulevaisuushorisontit olivat koulutuksen kautta työelämään orientoituvia siirtymiä, mikä on yhteiskunnan odotusten mukainen tapa integroitua yhteiskuntaan (Lähteenmaa 2010). Ensin mennään esimerkiksi ammatilliseen koulutukseen, sitten suunnataan palkkatyöhön. Paltamon työllisyyskokeilua koskevassa arviointitutkimuksessa tutkijat tulkitsivat, että myös sosiaaliseen ja ammatilliseen kuntoutukseen liittyy yhteiskunnallinen odotus siitä, että kuntoutus kykenee vahvistamaan reittejä työelämään (Saikku \& Kokko 2012). Tämä pätee myös kuntouttavaan työtoimintaan. Käytännössä osallistujien kannalta myönteiset sosiaalipoliittiset tai työllisyyttä tukevat siirtymät työtoiminnasta pois ovat kuitenkin erittäin vähäisiä tämän ja aikaisempien tutkimusten valossa (esim. Karjalainen \& Karjalainen 2010; Mäntyneva \& Isola 2019).

Keskeisin tutkimuksen johtopäätös on, että ilman myönteisiä siirtymiä työtoiminnan luoma toivo jää katteettomiksi lupauksiksi ja yltiöoptimismiksi. Tämä heikentää luottamusta järjestelmään. Vaarana on, että niin työtoimintaan osallistujista kuin työntekijöistä tulee Arlie Hochschildin (1979) kuvaamia emootiotyöntekijöitä, joista ensiksi mainitut pyrkivät saavuttamaan menetettyä itsearvostusta ja jälkimmäiset joutuvat asiakkaiden suostuttelussa ja rohkaisupolitiikan toteuttamisessa tyytymään olemassa olevien palveluiden reunaehtoihin ja polkuihin harkintavaltansa puitteissa. Osallistujat suorittavat ikään kuin yhteiskunnallista palvelus- 
taan ja ylläpitävät työkuntoaan. He ovat osa työttömien ja kuntoutujien reserviä, jonka toimintakyvyt ja -valmiudet eivät tule kuitenkaan osaksi yhteisen hyvän pyrkimyksiä. Kuntouttavaan työtoimintaan osallistuvien tilannetta voi verrata Freiren tallentavan kasvatuksen käsitteeseen. Sillä hän viittasi kasvatukseen, jossa on vastaanottava ja sopeutuva asenne erotukseksi asioita kyseenalaistavasta ja problematisoivasta asenteesta (Freire 2005, 75-93; ks. myös Tomperi \& Piattoeva 2005, 268). Pitkäaikaistyöttömien aktivoinnilla ja työtoiminnalla voi siten - hyvistä aikomuksista huolimatta - olla kielteisiä vaikutuksia. Vallan puutteen takia osallisuus voi jäädä osallistumiseksi ja sopeutumiseksi vallitseviin epätyydyttäviin olosuhteisiin ja osallistuminen heikentää itsearvostuksen kokemuksia entisestään emansipatoristen pyrkimysten ja nykyisiin yhteiskunnallisiin rakenteisiin kriittisesti asennoitumisen sijaan (Hänninen 2014; Mäntyneva \& Hiilamo 2018; Ryynänen \& Nivala 2017).

Toisaalta hyvinvointivointivaltion palvelut ja tulonsiirrot ovat ja luovat aitoja toimintamahdollisuuksia. Mikäli kuntouttava työtoiminta tai mikä tahansa palvelu onnistuu antamaan apua "kasvamaan saattaen", auttaa löytämään realistisia lähitulevaisuuden suunnitelmia, jollainen voi olla myös nykyisen elämäntilanteen ylläpitäminen, tai aikaansaa toivottua muutosta, vahvistaa se hyvää elämää. Jollekin eläkkeelle pääsy tai kuntoutukseen ja hoitoon pääsy voi olla toivottu muutos ja voimauttava asia työttömyyteen verrattuna. Osa tarvitsisi pitkäaikaisempaa tukea ja osallistumista mielekkääseen toimintaan, joka turvaisi toimeentulon esimerkiksi kansalaispalkan tai perustulon tavoin. Osalle pitkään työttömänä olleista erilaiset liittymiset kansalaisyhteiskuntaan ja esimerkiksi harrastustoimintaan yhteiskunnan tuella voivat tarjota myönteisiä osallisuuden kokemuksia (vrt. Siisiäinen 2014). Nykyisen työtoiminnan laventaminen vapaaehtoisuuden ja sisältöjen moninaisuuden suuntaan on nähty yhtenä vaihtoehtona pitkään työttömänä olleiden tilanteisiin etenkin nuorten kohdalla (Hiilamo ym. 2017; 2018). Osaa työttömistä voisi palvella työtakuun kaltainen toimintatapa tai tuetun työllistymisen malli. Kriittisesti olisi pohdittava lisäksi sitä, millaista on se työelämä, jossa olisi kaikille sijaa. Nykyisellään siirtymä työelämään ei johda väistämättä toimijuuden vahvistumiseen ja koettuun osallisuuteen. Nyky-yhteiskunnan moninaistuva käsitys palkkatyöstä ja kilpaillut työmarkkinat voivat aiheuttaa uudenlaisia epävarmuuksia, jos työelämän laatuun tai toimeen tulemisen edellytyksiin ei kiinnitetä huomiota.

Eriarvoisuutta käsitellyt työryhmä on ehdottanut kuntouttavaa työtoi- 
mintaa kehitettävän sosiaalisen toimintakyvyn tukemisen ja osallisuuden edistämisen näkökulmasta silloin, kun osallistumisen perimmäinen syy ei ole palkkatyön puute. Riittävä ajan resursointi, monialainen verkostoyhteistyö sekä asiakkaan tilanteisten voimavarojen huomioon ottaminen kuntoutumisprosessissa ovat raportin mukaan edellytyksenä onnistumiselle. Ihmiset tulisi ottaa mukaan yhteiskehittämään palvelujen sisältöjä ja osallistumaan demokraattiseen päätöksentekoon, mikä vahvistaisi osaltaan palvelujen emansipoivia elementtejä. (Eriarvoisuutta käsittelevän työryhmän loppuraportti 2018). Palvelujärjestelmässä jaetun vallan ja yhteistoiminnallisuuden avulla voi syntyä uudenlaista muutosta ja liikettä, jossa on sijaa sekä persoonakeskeiselle lähestymistavalle että kollektiiviselle toimijuudelle. Valtakunnallisessa sosiaalisen kuntoutuksen kehittämishankkeessa sosiaalisen kuntoutumisen keskeiseksi elementiksi on hahmotettu tiedostamisen prosessi, jossa minä-tuntemuksen ja itseluottamuksen syvenemisen sekä oman elämäntilanteen ja ympäröivän todellisuuden kriittisen reflektion myötä vahvistuvat myös ihmisen resurssit muutokseen (Raivio 2018).

Inklusiivinen eli mukaan ottava yhteiskunnallinen osallisuus ei ole vielä toistaiseksi kaikille yhteistä todellisuutta vaan pikemmin utooppinen horisontti tai ideaali. Kuitenkin valintoja siitä, millaisten suhteiden varassa yhteiskuntaa luodaan tulevaisuudessa, tehdään parasta aikaa. Monet tutkijat ovat yhtä mieltä siitä, että yksilöön kohdistuva yhteiskuntaan mukauttava ja integroiva yhteiskuntapolitiikka ja sosiaalityön keinot eivät yksistään riitä ratkaisemaan ihmisten kutistuvia toimintamahdollisuuksia ja esimerkiksi työttömyyden takia syrjäytettyjen elämäntilanteita (esim. Isola \& Siukola 2017, 126; Juhila 2002; Kivipelto \& Saikkonen 2017; Ryynänen \& Nivala 2017). Yhteiskunnassa tulisi löytää uudenlaisia sosiaalipoliittisia tulkintoja ja kysyntälähtöisiä mahdollisuusrakenteita sekä hallittuja riskinottoja. Niissä asiakas ymmärretään oman elämänsä asiantuntijana ja toimijana, jolla on voimavaroja ja elämänkulussaan karttunutta kokemustietoa (Pohjola 2017, 309; Hiilamo \& Saari 2010). Integraatiopolitiikan ymmärtäminen nykyistä pluralistisemmin assimiloivien tai segregoivien toimien sijaan sekä ihmisten erilaisten elämäntilanteiden ja elämänkulkujen huomiointi avaisivat tilaa myös uusille yhteiskunnallisille toimintamahdollisuuksille. Loppujen lopuksi kyse on Freiren (1972; 2005, 150; Hannula 2000, 136) tiedostamisprosessiin tukeutuen arvovalinnoista ja siitä, miten maailmaa voidaan muuttaa yhteistyöllä ja kestävällä tavalla kohti inhimillisempää yhteiskuntaa. 


\section{LÄHTEET}

Adams, R. 1993. Social work and Empowerment. London: Macmillan Press Ltd.

Aho, S. \& Mäkiaho A. 2016. Krooninen työttömyys. Pitkään avoimien työmarkkinoiden ulkopuolella olleiden työttömien määrää ja rakennetta sekä työttömyyden dynamiikkaa Suomessa vuosina 2005-2013 selittävä tutkimus. Valtioneuvoston kanslian julkaisusarja 20/2016. Helsinki: Valtioneuvoston kanslia. Saatavissa http:// urn.fi/URN:ISBN:978-952-287-254-8 (haettu 1.8.2018).

Campbell, M. L. \& Gregor, F. M. 2004. Mapping Social Relations: A Primer in Doing Institutional Ethnography. Lanham (MD): AltaMira Press.

Certaux, M. de. 1984. The Practice of Everyday Life. Berkeley: University of California Press.

Coffey, A. \& Atkinson, P. 1996. Making Sense of Qualitative Data: Complementary Research Strategies. Thousands Oaks (CA): Sage.

Elder, G. H. Jr. \& Johnson, M. K. 2003. The life course and aging: Challenges, lessons, and new directions. Teoksessa R. A. Setterson Jr. (Ed.) Invitaton to life course. Towards new understanding of later life. Amityville, NY: Baywood, 49-81.

Elonen, N. \& Niemelä, J. \& Saloniemi, A. 2017. Aktivointi ja pitkäaikaistyöttömien monenlainen toimijuus. Janus 25 (4), 280-296. Saatavissa https://journal.fi/janus/ article/view/60756/27928 (haettu 1.11.2019).

Eriarvoisuutta käsittelevän työryhmän loppuraportti 2018. Valtioneuvoston kanslian julkaisusarja 1/2018. Helsinki: Valtioneuvoston kanslia. Saatavissa http://urn.fi/ URN:ISBN:978-952-287-557-0 (haettu 1.8.2018).

Filatov, T. 2013. Selvitystyö välityömarkkinoiden mahdollisuuksista tukea vaikeasti työllistyvien työelämään osallistumista ja työmarkkinoille pääsyä. Selvityshenkilö Tarja Filatovin raportti työministeri Lauri Ihalaiselle. TEM raportteja 7/2013. Helsinki: Työ- ja elinkeinoministeriö.

Freire, P. 1972. Pedagogy of the Oppressed. 2nd ed. London: Penguin Books.

Freire, P. 2005. Sorrettujen pedagogiikka. Tampere: Vastapaino.

Frost, L. \& Hoggett, P. 2008. Human Agency and Social Suffering. Critical Social Policy 28 (4), 438-460. https://doi.org/10.1177/0261018308095279.

Giddens, A. 1984. The constitution of society. Outline of the theory of structuration. Cambridge: Polity.

Giroux, H. 2000. Rethinking Education as the Practice of Freedom: Paulo Freire and the promise of critical pedagogy. Policy Futures of Education 8 (6), 715-721.

Hammersley, M. \& Atkinson, P. 2007. Ethnography. Principles in practice. Third Edition. First published in 1983. London, New York: Routledge.

Hannula, A. 2000. Tiedostaminen ja muutos Paulo Freiren ajattelussa. Systemaattinen analyysi Sorrettujen pedagogiikasta. Helsingin yliopiston kasvatustieteen laitoksen tutkimuksia 167. Helsinki: Helsingin yliopisto. 
Hietala, O. 2013. A-klinikan asiakaskahvilassa: etnografinen tutkimus asiakkaiden juomiselle ja ammattiavulle antamista merkityksistä. Diakonia ammattikorkeakoulun julkaisuja A, Tutkimuksia, 37. Helsinki: Diakonia-ammattikorkeakoulu.

Hietala, O. 2018. Sosiaalisen kuntoutuksen yhteiskehittämisessä osallisuus avautuu kaikille. Teoksessa H. Kostilainen \& A. Nieminen (toim.) Sosiaalisen kuntoutuksen näkökulmia ja mahdollisuuksia. Työelämän raportteja 13. Helsinki: Diakoniaammattikorkeakoulu, 118-138.

Hiilamo, H., Komp, K., Moisio, P., Babila, S. T., Lauronen, J., Karimo, A., Mäntyneva, P., Parpo, A. \& Aaltonen, H. 2017. Neljä osallistavan sosiaaliturvan mallia. Valtioneuvoston selvitys- ja tutkimustoiminnan julkaisusarja: 18/2017. Helsinki: Valtioneuvoston kanslia. Saatavissa http://urn.fi/URN:ISBN:978-952-287-351-4 (haettu 8.2.2017).

Hiilamo, H., Määttä, A., Koskenvuo, K., Pyykkönen, J., Räsänen, T. \& Aaltonen, S. 2018. Nuorten osallisuuden edistäminen. Selvitysmiehen raportti. Saatavissa http://urn.fi/ URN:ISBN:978-952-493-298-1 (haettu 18.8.2017).

Hiilamo, H. \& Saari, J. 2010. Sosiaalisten mahdollisuuksien politiikka. Teoksessa H. Hiilamo \& J. Saari (toim.) Hyvinvoinnin uusi politiikka. Johdatus sosiaalisiin mahdollisuuksiin. Diakonia-ammattikorkeakoulun julkaisuja. Tutkimuksia A 27. Helsinki: Diakonia-ammattikorkeakoulu, 13-36. Saatavissa https://core.ac.uk/ download/pdf/161422312.pdf (haettu 1.8.2018).

Hochschild, A. R. 1979. Emotion Work, feeling rules, and social structure. American Journal of Sociology 85 (3), 551-575.

Hoggett, P. 2001. Agency, Rationality and Social Policy. Journal of Social Policy 30 (1), $37-56$.

Hokkanen, L. 2014. Autetuksi tuleminen. Valtaistavan sosiaalisen asianajon edellyttämät toimijuudet. Rovaniemi: Lapin yliopisto, Acta Electronica Universitatis Lapponiensis 145. Saatavissa https://lauda.ulapland.fi/handle/10024/61787 (haettu 1.8.2017).

Honneth, A. 1995. The I in We: Studies in the Theory of Recognition. The Moral Grammar of Social Conflicts. Cambridge (MA): Polity Press.

Honneth, A. 2012. The I in We: studies in the theory of recognition. Cambridge (MA): Polity Press.

Hämäläinen, J. 2015. Defining Social Pedagogy: Historical, Theoretical and Practical Considerations. British Journal of Social Work 45, 1022-1038. Saatavissa https://doi. org/10.1093/bjsw/bct174 (haettu 3.11.2019).

Hänninen, S. 2014. Työttömän työnhakijan mahdoton mahdollisuus. Teoksessa K. Lempiäinen \& T. Silvasti (toim.) Eriarvoisuuden rakenteet. Haurastuvat työmarkkinat Suomessa. Tampere: Vastapaino, 184-208.

Isola, A-M. \& Siukola, R. 2017. Arvottomat. Köyhien naisten ja miesten kokemuksia arvokkuudesta suomalaisessa hyvinvointivaltiossa. Teoksessa S. Hänninen \& P. Saikkonen (toim.) Hyvinvointivaltio ylittää jälkensä. Helsinki: Terveyden ja hyvinvoinnin laitos, 111-128. 
Jokela, U. 2011. Diakoniatyön paikka ihmisten arjessa. Diakonia-ammattikorkeakoulu, A Tutkimuksia 34. Helsinki: Diakonia-ammattikorkeakoulu.

Juhila K. 2002. Sosiaalityö marginaalissa. Teoksessa K. Juhila, H. Forsberg \& I. Roivainen (toim.) Marginaalit ja sosiaalityö. Jyväskylä: SoPhi 65, 11-19.

Juvonen, T. H. 2013. Nuorten aikuisten autonomisen toimijuuden jännitteinen rakentuminen ammatillisen etsivän työn kontekstissa. Teoksessa M. Laitinen \& A. Niskala (toim.). Asiakkaat sosiaalityön toimijoina. Tampere: Vastapaino, 327-356.

Jyrkämä, J. 2008. Toimijuus, ikääntyminen ja arkielämä - hahmottelua teoreettismetodologiseksi viitekehykseksi. Gerontologia 22 (4), 190-203.

Järvikoski, A. 2013. Monimuotoinen kuntoutus ja sen käsitteet. Helsinki: Sosiaalija terveysministeriön raportteja ja muistioita 2013:43. Saatavissa http://urn.fi/ URN:ISBN:978-952-00-3457-3 (haettu 3.11.2019).

Kallio, K. P., Korkiamäki, R. \& Häkli, J. 2015. Myönteinen tunnistaminen - näkökulma hyvinvoinnin edistämiseen ja syrjäytymisen ehkäisemiseen. Teoksessa J. Häkli, K. P. Kallio \& R. Korkiamäki (toim.) Myönteinen tunnistaminen. Helsinki: Nuorisotutkimusverkosto, Nuorisotutkimusseura, julkaisuja 171.

Karjalainen,J.\&Karjalainen, V.2010.Kuntouttavatyötoiminta:aktiivistasosiaalipolitiikkaa vai työllisyyspolitiikkaa? Empiirinen tutkimus pääkaupunkiseudulta. Helsinki: Terveyden ja hyvinvoinnin laitos, raportti 38. Saatavissa http://urn.fi/URN:NBN:fife201205085148 (haettu 3.11.2019).

Kivipelto, M. \& Saikkonen, P. 2017. Sosiaalityö ekologisiin rajoihin mahtuvassa hyvinvointivaltiossa? Teoksessa S. Hänninen \& P. Saikkonen (toim.) Hyvinvointi ylittää jälkensä. Helsinki: Terveyden ja hyvinvoinnin laitos, 25-39.

Kostilainen, H. \& Nieminen, A. 2018. Sosiaalisen kuntoutuksen näkökulmia ja mahdollisuuksia. Helsinki: Diakonia-ammattikorkeakoulu, Diak Työelämä 13. Saatavissa http://urn.fi/URN:ISBN:978-952-493-307-0 (haettu 3.11.2019).

Kotiranta, T. 2008. Aktivoinnin paradoksit. Jyväskylä Studies in Education, Psychology and Social Research 225. Jyväskylä: Jyväskylän yliopisto. Saatavissa http://urn.fi/ URN:ISBN:978-951-39-3250-3 (haettu 3.11.2019).

Kuure, T. 2015. Sosiaalinen vahvistaminen käsitteenä ja palveluina. Sosiaalisen vahvistamisen kehittämistoiminnan tuloksia. Helsinki: Valtakunnallinen työpajayhdistys ry.

Laitinen, M. \& Niskala, A. (toim.) 2013. Asiakkaat toimijoina sosiaalityössä. Tampere: Vastapaino.

Lassander, M., Solin, P., Tamminen N. \& Stengård, E. 2013. Asiakkaan voimaantuminen mielenterveyspalveluissa. Tarkastelussa WHO:n voimaantumisen indikaattorit. Yhteiskuntapolitiikka 78 (6), 685-691 Saatavissa http://urn.fi/URN:NBN:fife2014040923352 (haettu 3.11.2019).

Lister, R. 2004. Poverty. Cambridge: Polity.

Luhtasela, L. 2009. Osallisuuden rakentuminen kuntouttavassa työtoiminnassa. Helsinki: Helsingin yliopisto. Saatavissa http://hdl.handle.net/10138/16493 (haettu 3.11.2019). 
Lähteenmaa, J. 2010. Nuoret työttömät ja taistelu toimijuudesta. Työpoliittinen Aikakauskirja 53 (4), 51-63.

Merleau-Ponty, M. 2012. Filosofisia kirjoituksia. Toim. ja suom. M. Luoto \& T. Roinila, Helsinki: Nemo.

Mullainathan, S. \& Shafir, E. 2013. Scarcity: Why having too little means so much. New York, NY, US: Times Books/Henry Holt and Co.

Mäntyneva, P. \& Hiilamo, H. 2018. Osallisuuden ja osattomuuden dynamiikka työtoiminnassa. Etnografinen tutkimus kolmella kuntouttavan työtoiminnan kentällä. Yhteiskuntapolitiikka 83 (1), 18-28. Saatavissa https://www.julkari.fi/ bitstream/handle/10024/136023/YP1801_Mantyneva\%26Hiilamo.pdf?sequence=2 (haettu 3.11.2019).

Mäntyneva, P. \& Isola, A-M. 2019. Toimintamahdollisuuksien avaruus ja toimijuuden suunnat kuntouttavassa työtoiminnassa. Janus 27 (3), 246-263. Saatavissa https://doi. org/10.30668/janus.70286 (haettu 3.11.2019).

Nussbaum, M. 2011. Creating capabilities: the human development approach. Cambridge (MA): The Belknap Press of Harvard University Press.

Pirhonen, J. 2017. Good Human Life in Assisted Living for Older People: What the residents are able to do and be. Acta Universitatis Tamperensis. Tampere: Tampereen yliopisto. Saatavissa https://trepo.tuni.fi/handle/10024/101042 (haettu 3.11.2019).

Pohjola, A. 2017. Asiakkaan pitkä tie palveluihin vaikuttajaksi. Teoksessa A. Pohjola, M. Kairala, H. Lyly \& A. Niskala (toim.) Asiakkaasta kehittäjäksi ja vaikuttajaksi Asiakkaiden osallisuuden muutos sosiaali- ja terveyspalveluissa. Tampere: Vastapaino, 308-325.

Pohjola, A., Kairala, M., Lyly, H. \& Niskala, A. (toim.) 2017. Asiakkaasta kehittäjäksi ja vaikuttajaksi - Asiakkaiden osallisuuden muutos sosiaali- ja terveyspalveluissa. Tampere: Vastapaino.

Raivio, H. 2018. Sosiaalinen kuntoutus voimavaraistamisena - toivon ja muutoksen näkökulma. Teoksessa H. Kostilainen \& A. Nieminen (toim.) Sosiaalisen kuntoutuksen näkökulmia ja mahdollisuuksia. Helsinki: Diakonia-ammattikorkeakoulu, työelämän raportteja 13. Saatavissa http://urn.fi/URN:ISBN:978-952-493-307-0 (haettu 3.11.2019).

Rajavaara M. 2007. Vaikuttavuusyhteiskunta. Sosiaalisten olojen arvostelusta vaikutusten todentamiseen. Sosiaali- ja terveysturvan tutkimuksia 84. Helsinki: Kelan tutkimusosasto. Saatavissa http://urn.fi/URN:ISBN:978-951-669-733-1 (haettu 3.11.2019).

Ronkainen, S. 1999. Ajan ja paikan merkitsemät: subjektiviteetti, tieto ja toimijuus. Helsinki: Gaudeamus.

Ruuskanen, P. T. \& Savolainen, K. \& Suonio, M. (toim.) 2011. Toivo sosiaalisessa. Toivoa luova toimintakulttuuri sosiaalityössä. Kuopio: UNIpress, 172-188.

Ryynänen, S. \& Nivala, E. 2017. Empowerment or emancipation? Interpretations from Finland and beyond. Pedagogía Social. Revista Interuniversitaria 30, 33-46. Saatavissa https://doi.org/10.7179/PSRI_2017.30.03. (haettu 3.11.2019). 
Saikku P. \& Kokko, R. 2012. Kuntoutuksen käytännöt Paltamon työllisyyskokeilussa. Toimijuuden tukeminen ammatillisessa ja sosiaalisessa kuntoutuksessa. Kuntoutus $35(4), 5-16$.

Saleebey, D. 2000. Power in the People: Strengths and Hope. Advances in Social Work 1 (2), 127-136.

Sandelin, I. 2014. Kuntouttava työtoiminta asiakkaiden kokemana - Kirjallisuuskatsaus asiakkaiden toiminnalle antamista merkityksistä. Terveyden- ja hyvinvoinnin laitoksen työpapereita 8/2014. Helsinki: Terveyden ja hyvinvoinnin laitos. Saatavissa http://urn.fi/URN:ISBN:978-952-302-154-9 (haettu 3.11.2019).

Sen, A. 1993. Developments as freedoms. New York: Anchor Books.

Shove, E., Pantzar, M. \& Watson, M. 2012. The dynamics of Social Practice. Everyday Life and How it Changes. London: Sage.

Siisiäinen, M. 2014. Työtä vailla olevat nuoret. Teoksessa K. Lempiäinen \& T. Silvasti (toim.) Eriarvoisuuden rakenteet. Haurastuvat työmarkkinat Suomessa. Tampere: Vastapaino, 91-125.

Siitonen, J. 1999. Voimaantumisteorian perusteiden hahmottelua. Oulu: Oulun yliopisto, Oulun opettajankoulutuslaitos.

Smith D. E. 1987. The Everyday World as Problematic. A Feminist Sociology. Boston: Northeastern University Press.

Smith, D. E. 2005. Institutional Ethnography: Sociology for People. Oxford: AltaMira Press.

Smith D. E. (Ed.) 2006. Institutional Ethnography as Practice. Oxford: Rowman \& Littlefield.

Spradley, J. P. 1979. Ethnographic Interviews. New York: Holt, Rinehart \& Winston.

Sosiaalihuollon työelämäosallisuutta tukevan lainsäädännön ja palvelujärjestelmän uudistamistarpeita arvioivan työryhmän loppuraportti 2014. Helsinki: Sosiaalija terveysministeriö. Raportteja ja muistioita 2014:32. Saatavissa http://urn.fi/ URN:ISBN:978-952-00-3524-2 (haettu 3.11.2019).

Suoranta, J. \& Ryynänen, S. 2014. Taisteleva tutkimus. Helsinki: Into.

Tammelin, M. 2010. Kokemuksia sosiaalipalveluista: Kuntouttavan työtoiminnan asiakasfoorumit Keski-Suomessa. Helsinki: Terveyden- ja hyvinvoinnin laitos. Saatavissa http://urn.fi/URN:NBN:fi-fe201205085134 (haettu 3.11.2019).

Taylor C. 1992 Multiculturalism and the Politics of Recognition. Princeton (NJ): Princeton University Press.

Tomperi, T. \& Piattoeva, N. 2005. Demokraattisten juurten kasvattaminen. Teoksessa T. Kiilakoski, T. Tomperi \& M. Vuorikoski (toim.) Kenen kasvatus? Kriittinen pedagogiikka ja toisinkasvatuksen mahdollisuus. Tampere: Vastapaino, 247-286.

Van Heertum, R. 2006. Marcuse, Bloch and Freire: reinvigorating a pedagogy of hope. Policy Futures in Education 4 (1), 45-51. Saatavissa https://doi.org/10.2304/ pfie.2006.4.1.45 (haettu 3.11.2019). 
Virtanen, A. 2017. Kuntouttava työtoiminta 2016 - Kuntakyselyn osaraportti. Arbetsverksamhet i rehabiliteringssyfte 2016 - Delrapport om kommunenkäten. THL:n Tilastoraportti 33/2017. Helsinki: Terveyden ja hyvinvoinnin laitos.

Väisänen, R. 2011. Toivon ja epätoivon rajapinnoilla. Näkökulmana ehkäisevä päihdesosiaalityö. Teoksessa P. T. Ruuskanen, K. Savolainen \& M. Suonio (toim.) Toivo sosiaalisessa. Toivoa luova toimintakulttuuri sosiaalityössä. Kuopio: UNIpress, $172-188$.

Välimaa, A., Ylipaavalniemi, P., Pikkusaari, S. \& Hassinen, M. 2012. Sosiaalisen työllistämisen toimiala. Palveluilla tasa-arvoa työllisyyteen. Helsinki: Valtakunnallinen työpajayhdistys ry ja VATES-säätiö.

Weckroth, K. 1992. Toiminnan psykologia. 2. painos. Helsinki: Hanki ja jää. 